\title{
Isolation and Characterization of Red Bean and Green Bean Protein using the Extraction Method and Isoelectric $\mathrm{pH}$
}

\author{
Slamet Hadi Kusumah ${ }^{\text {a, }}$, Robi Andoyo ${ }^{\text {a* }}$, Tita Rialita ${ }^{a}$ \\ ${ }^{a}$ Department of Agroindustrial Technology, Faculty of Agricultural Industrial Technology, Universitas Padjadjaran, Indonesia. \\ ${ }^{b}$ Department of Food Technology, Faculty of Engineering, Universitas Islam Al-Ihya Kuningan, Indonesia.
}

Received 20 March 2020; Accepted 16 May 2020

\begin{abstract}
Stunting children need food intake with higher protein and essential amino acids such as lysine and leucine than normal children. Red Beans (Phaseolus Vulgaris L.) and Green Beans (Phaseolus Radiatus L.) have protein content, respectively $22.07 \pm 0.13 \%$ and $19.99 \pm 0.07 \%$, and are rich in essential amino acids lysine and leucine needed by a stunting child. The Development of food products with high protein concentrations (high protein food) such as isolates/protein concentrates is an important subject that must be done. This study aims to determine the technique of isolating red bean and green bean protein through extraction and deposition methods at isoelectric $\mathrm{pH}$. The research method used is an experimental method with descriptive data analysis. Identification of isoelectric $\mathrm{pH}$ of red bean and green bean protein is done through electrophoretic mobility $\left(\mathrm{cm}^{2} / \mathrm{Vs}\right)$ testing on samples that have been conditioned at 3 different depositional $\mathrm{pHs}$ namely $\mathrm{pH} 3.00,4.00$, and 5.00. The results showed the isoelectric $\mathrm{pH}$ value of red bean and green bean protein, namely $\mathrm{pH} 4.56$ and $\mathrm{pH} 4.81$ respectively, where the $\mathrm{pH}$ had electrophoretic mobility values equal to zero. The process of isolating red bean and green bean protein produces protein powder with a protein content of $79.22 \pm 0.06 \%$ and $80.69 \pm$ $0.06 \%$, respectively. Based on the weight yield, red bean and green bean protein concentrate powder had a yield of $14.88 \%$ and $16.75 \%$, respectively.
\end{abstract}

Keywords: Protein Isolation; Extraction; Isoelectric pH; Red Beans; Green Beans.

\section{Introduction}

The percentage of stunting in West Java at this time is $34.51 \%$ which is spread in several districts including Sukabumi, Cianjur, Cirebon and Garut [1]. Stunting is defined as a state with a height below 2 standard deviations from the median on the height growth curve. The causes and risk factors for stunting occur due to internal factors such as genetic or external factors such as poor nutrition and chronic infections. Stunting children have lower essential amino acids such as lysine and leucine compared to normal children [2]. Therefore, the development of food products with high protein concentrations and containing essential amino acids is an important subject that must be done.

Some agricultural commodities such as milk, red beans, and green beans can be used as a source of protein that can be used as a structural component and provide nutritional value in high-protein foods. West Java local commodities that have the potential as a source of plant protein are Green Beans (Phaseolus Radiatus L.) and Red Beans (Phaseolus vulgaris $L$.) with protein content of about $22 \%$ and $29 \%$, respectively. The content of essential amino acids of green beans is quite complete, namely isoleucine, leucine, lysine, methionine, phenylalanine, threonine, and valine [3]. Red bean and green bean proteins can be used as structural components and provide nutritional value in high-protein foods.

\footnotetext{
* Corresponding author: r.andoyo@unpad.ac.id

$>$ This is an open access article under the CC-BY license (https://creativecommons.org/licenses/by/4.0/).

(C) Authors retain all copyrights.
} 
At present the use of green beans and red beans is focused on starch and ignores the development of protein in green beans and red beans [4]. Seeing the high protein content, green beans and red beans can be processed into powder isolates or protein concentrates [4-6]. The use of isolates or concentrates of green bean and red bean protein can be a source of vegetable protein preparations for various high-protein food products.

The process of isolating protein legumes begins with the process of extracting protein in an alkaline solution. In alkaline conditions, the extraction process will produce more protein and dissolved protein will be easily separated from the residue. Red bean and green bean protein concentrate / concentrate is obtained by precipitating the protein at its isoelectric point. At the isoelectric point, protein solubility decreases and reaches the lowest number where the protein will precipitate and clot. Some researchers adjust the isoelectric point at $\mathrm{pH}$ 3.7-5.5 so that it produces different yields and characteristics [7-9]. Certain varieties of red beans and green beans have various amino acids. Each amino acid has a different isoelectric point [10]. The purpose of this study was to determine the technique of isolating red bean and green bean protein through extraction and deposition methods at isolectic $\mathrm{pH}$ to produce isolates or protein concentrates with good profiles.

\section{Material and Methods}

\subsection{Material}

Red beans (Phaseolus Vulgaris L.) are taken from farmers in Argapura Subdistrict, Majalengka Regency, while Green Beans (Phaseolus Radiatus L.) are taken from farmers in the Ciwaringin District of Cirebon Regency. Aquades is used as a solvent in the process of protein extraction. $0.5 \mathrm{~N}$ sodium hydroxide $(\mathrm{NaOH})$ is used to adjust the base $\mathrm{pH}$ of the extraction process.

\subsection{Characterization of Raw Materials}

In the preliminary research stage characterization of raw materials was carried out through proximate analysis and amino acids. Proximate analysis needs to be done in order to determine the chemical content of the raw material, so as to determine the part of the bean used for protein isolation. Proximate analysis includes testing water content, ash content, fat content of the Soxhlet method, protein content of the Kjeldhal method, and carbohydrate content by difference $[11,12]$.

The parts of the bean that will be identified through proximate analysis are the parts of the epidermis, whole bean seeds, and peanut seeds without epidermis. It aims to see the potential of the bean parts so that they can determine and choose the bean parts used for protein isolation proteins. The selected bean part will then be carried out a flouring process to produce red bean flour and green beans with a particle size of 80 mess. Amino acid test is carried out on red bean flour and green beans to determine the potential of amino acids in the selected bean parts. Amino acid testing uses HPLC and UPLC tools [13, 14].

\subsection{Identification of Isoelectric Points}

At this stage, isoelectric point identification is carried out to determine the $\mathrm{pH}$ settlement used in the next research stage. The isoelectric point identification technique in this study cites the method used by Andoyo, et. al., (2015) in identifying isoelectric points on whey protein using a Zetasizer. The isoelectric point is identified by conducting a zeta potential or electrophoretic mobility $\left(\mathrm{cm}^{2} / \mathrm{Vs}\right)$ test on a sample that has been conditioned at various depositional pHs [15].

Determination of the isoelectric point is done by finding a linear equation from the electrophoretic mobility values that are already known at 3 settling $\mathrm{pH}$ points namely at $\mathrm{pH} 3.00 ; 4.00$; and 5.00. Next, enter the electrophoretic mobility value on the $\mathrm{y}$ axis and the $\mathrm{pH}$ value on the $\mathrm{x}$ axis using the Ms. Excel. Linear equations and $\mathrm{R}^{2}$ values can be found automatically in the trendline menu. The value of $x$ is $\mathrm{pH}$, while $y$ is electrophoretic mobility. The isoelectric $\mathrm{pH}$ value is the $\mathrm{pH}$ value with electrophoretic mobility $\left(\mathrm{cm}^{2} / \mathrm{Vs}\right)$ equal to zero [15]. Then the result of the $x$ value at $y=0$ is the isoelectric $\mathrm{pH}$. Then to determine the isoelectric $\mathrm{pH}$ value one must look for the $x$ value at $y=0$.

Verification is carried out by carrying out a protein test on the precipitate protein of red beans and green beans which are isolated under depositional $\mathrm{pH} 3.00 ; 4.00 ; 5,00$, and isoelectric $\mathrm{pH}$. Under the isoelectric $\mathrm{pH}$ deposition conditions, red bean and green bean protein deposits have the highest protein content compared to the others [16].

\subsection{The Process of Protein Isolation}

The process of isolating red bean and green bean protein modifies the method carried out by Wang et al. (2011) through extraction under alkaline conditions and continued with the deposition process at isoelectric $\mathrm{pH}$. The protein isolation process will be made from $40 \mathrm{~g}$ of red bean flour or green bean flour. Mixing ingredients with the ratio of red bean flour: distilled water is 1: $10(\mathrm{w} / \mathrm{w})$. Then stir for 3 minutes, then check the initial $\mathrm{pH}$. Adjust the extraction $\mathrm{pH}$ by adding $0.5 \mathrm{~N} \mathrm{NaOH}$ to reach $\mathrm{pH} 8.50$.

The protein extraction process is carried out at $30^{\circ} \mathrm{C}$ for 30 minutes. The same thing is also done on green bean flour samples. In alkaline conditions, the extraction process will produce more protein and dissolved protein will be 
easily separated from the residue. However, alkaline conditions will also damage amino acids containing sulfur such as tryptophan, threonine, lysine, and methionine [17].

Separation I was carried out using centrifugation at a speed of 4000-4500 rpm for 15 minutes. The aim is to separate the supernatant and the residue. Supernatant is a dissolved protein [17, 18]. Supernatant is taken for the deposition process. Supernatant is added with $2 \mathrm{~N} \mathrm{HCl}$ for the $\mathrm{pH}$ adjustment process to reach isoelectric $\mathrm{pH}$. The deposition process was carried out at $30^{\circ} \mathrm{C}$ for 10 minutes. The separation process II is carried out using centrifugation, carried out at speeds of 4000 - $4500 \mathrm{rpm}$ for 15 minutes. The resulting sludge contains most of the red bean and green bean protein which have been separated from other components [4, 7]. The resulting protein deposit was then dried with freeze drying at $-50^{\circ} \mathrm{C}$ for 24 hours. The red bean and green bean protein powder were then characterized using the Kjeldhal method protein content test and the water content test [12].

\section{Result and Discussion}

\subsection{Characterization of Raw Materials}

The following are the results of a proximate analysis performed on red beans and green beans, namely the whole bean seeds, peanut seeds without epidermis, and epidermis.

Table 1. Proximate analysis of raw materials

\begin{tabular}{|c|c|c|c|c|c|}
\hline Sample & $\begin{array}{c}\text { Water content } \\
(\%)\end{array}$ & $\begin{array}{c}\text { Ash content } \\
(\%)\end{array}$ & $\begin{array}{c}\text { Fat level } \\
(\%)\end{array}$ & $\begin{array}{c}\text { Protein content } \\
(\%)\end{array}$ & $\begin{array}{c}\text { Carbohydrates level } \\
(\%)\end{array}$ \\
\hline Whole red beans & $12.54 \pm 0.27$ & $3.15 \pm 0.02$ & $1.97 \pm 0.03$ & $22.07 \pm 0.13$ & $60.29 \pm 0.09$ \\
\hline Whole green bean seeds & $10.06 \pm 0.28$ & $2.82 \pm 0.05$ & $1.28 \pm 0.05$ & $19.99 \pm 0.07$ & $65.86 \pm 0.30$ \\
\hline Red bean seeds without epidermis & $14.57 \pm 0.00$ & $3.07 \pm 0.06$ & $1.95 \pm 0.21$ & $21.75 \pm 0.19$ & $58.67 \pm 0.35$ \\
\hline Green bean seeds without epidermis & $14.05 \pm 1.93$ & $2.99 \pm 0.03$ & $1.24 \pm 0.07$ & $20.69 \pm 0.44$ & $61.04 \pm 2.41$ \\
\hline Red bean epidermis & $10.4 \pm 0.36$ & $3.51 \pm 0.20$ & $0.15 \pm 0.04$ & $5.97 \pm 0.03$ & $79.96 \pm 0.58$ \\
\hline Green bean epidermis & $10.06 \pm 0.30$ & $2.07 \pm 0.12$ & $0.06 \pm 0.00$ & $10.63 \pm 0.06$ & $77.19 \pm 0.35$ \\
\hline
\end{tabular}

\subsubsection{Water Content}

In Table 1, the water content of whole red beans is $12.54 \pm 0.27 \%$ lower than the beans without epidermis $14.57 \pm 0.00 \%$ and the portion of the epidermis of red beans $10.42 \pm 036 \%$. In green beans, whole green bean seeds and parts of the epidermis of green beans have the lowest water content of $10.06 \pm 0.28 \%$ and $10.06 \pm 0.30 \%$ respectively. While the green bean seeds without epidermis has a moisture content of $14.05 \pm 1.93 \%$.

Water is one of the most important characteristics of food because water can determine the acceptability, freshness, and durability of these foodstuffs. The minimum water content limit where microbes can still grow is 14 - 15\% [19]. The water content in food can affect the resistance of food ingredients to microbial attack expressed in aw, that is the amount of free water used by microorganisms for its growth. Thus, the moisture content of raw materials of red beans and green beans can be used for the process of protein isolation at a later stage because it has a moisture content $<15 \%$.

\subsubsection{Ash Content}

Ash is an inorganic substance from the combustion of an organic material. The ash content and composition depends on the type of material and how it is used. Ash content has something to do with minerals. Determination of ash content is by oxidizing all organic substances at high temperatures, which is around $600^{\circ} \mathrm{C}$ then weighing the substances left behind after the combustion process [20].

In Table 1, red bean seeds have higher ash content than green bean seeds. In red beans, the largest ash content was found in the epidermis of red beans by $3.51 \pm 0.20 \%$, while the ash content of whole red beans was $3.15 \pm 0.02 \%$ and red bean seeds without epidermis was $3,07 \pm 0.06 \%$.

In the green beans, the portion of the green bean without epidermis has the largest ash content of $2.99 \pm 0.03 \%$, compared to the whole green bean seeds and the portion of the epidermis of green beans is $2.82 \pm 0.05 \%$ and $2.07 \pm$ $0.12 \%$, respectively.

\subsubsection{Fat Level}

Fats and oils are important food substances to maintain the health of the human body. Fats are also a more effective source of energy compared to carbohydrates and proteins. Vegetable fats contain essential fatty acids such as linoleic and lenolenic acids which can prevent blood vessel constriction due to cholesterol build-up [19].

In Table 1, whole red beans and skinless red beans have nearly the same fat content, namely $1.97 \pm 0.03 \%$ and 1.95 
$\pm 0.21 \%$, respectively. Fat content of whole green bean seeds and green bean seeds without epidermis also have fat content that is not much different namely $1.28 \pm 0.05 \%$ and $1.24 \pm 0.07 \%$, respectively. This is due to the fat content in the epidermis of red red beans and green beans having a low fat content that is equal to $0.15 \pm 0.04 \%$ and $0.06 \pm$ $0.00 \%$, respectively. Red beans and green beans have low fat content. Low levels of fat in red beans and green beans cause food and beverage ingredients made from red beans and green beans are not easy to smell.

\subsubsection{Protein Content}

Protein is a food substance that is very important for the body, because in addition to functioning as fuel in the body but also as a builder and regulator. Proteins are polymers of amino acids associated with peptide bonds, protein molecules containing elements $\mathrm{C}, \mathrm{H}, \mathrm{O}$ and $\mathrm{N}$ that are not owned by fat or carbohydrates [10].

In Table 1, protein content of whole red bean seeds is $22.07 \pm 0.13 \%$, higher than red bean seeds without epidermis which is $21.75 \pm 0.19 \%$. Meanwhile, protein content of whole green bean seeds is $19.99 \pm 0.07 \%$, lower than that of green bean seeds without epidermis which is $20.69 \pm 0.44 \%$. In the epidermis of red red beans and green beans have a high enough protein content that is equal to $5.97 \pm 0.03 \%$ and $10.63 \pm 0.06 \%$. Thus, the process of protein isolation is done by using raw materials of whole red beans and whole green bean seeds so that all proteins contained in the epidermis, cotyledons, and institutions can be maximally isolated.

\subsubsection{Carbohydrate Levels}

Carbohydrates are organic compounds that contain carbon, hydrogen and oxygen atoms, and in general the elements hydrogen and oxygen in the composition produce $\mathrm{H}_{2} \mathrm{O}$ [3]. Carbohydrates have an important role in determining the characteristics of food ingredients, such as taste, color, texture and others. Carbohydrates are found in many plant foods, both in the form of simple sugars, hexoses, pentose, and high molecular weight carbohydrates such as starch, pectin, cellulose, and lignin [19].

In Table 1, whole red beans, red red beans without epidermis, and red bean epidermis contain carbohydrate content of $60.29 \pm 0.09 \%, 58.67 \pm 0.35 \%$, and $79.96 \pm 0.58 \%$. As for green beans, the carbohydrate content of whole green beans, green beans without epidermis, and green bean epidermis are $65.86 \pm 0.30 \%, 61.04 \pm 2.41 \%$, and $77.19 \pm 0$, $35 \%$, respectively.

\subsection{The Amino Acid Content of Red Bean Flour and Green Beans}

The results of testing the amino acid content of raw materials for red bean flour and green bean flour using the HPLC and UPLC methods can be seen in Figure 1. Red beans and green beans are a source of protein, where amino acids are the main constituent of protein which plays an important role for the human body. Essential amino acids cannot be produced in the body, whereas non-essential ones can be produced in the body [3]. Overall, the highest amino acid content in red bean flour and green bean flour was glutamic acid which was $32,617.49 \mathrm{mg} / \mathrm{kg}$ and $34,968.78 \mathrm{mg} / \mathrm{kg}$ (Figure 1). Glutamic acid is one type of non-essential amino acid, meaning that this amino acid can be produced in the body.

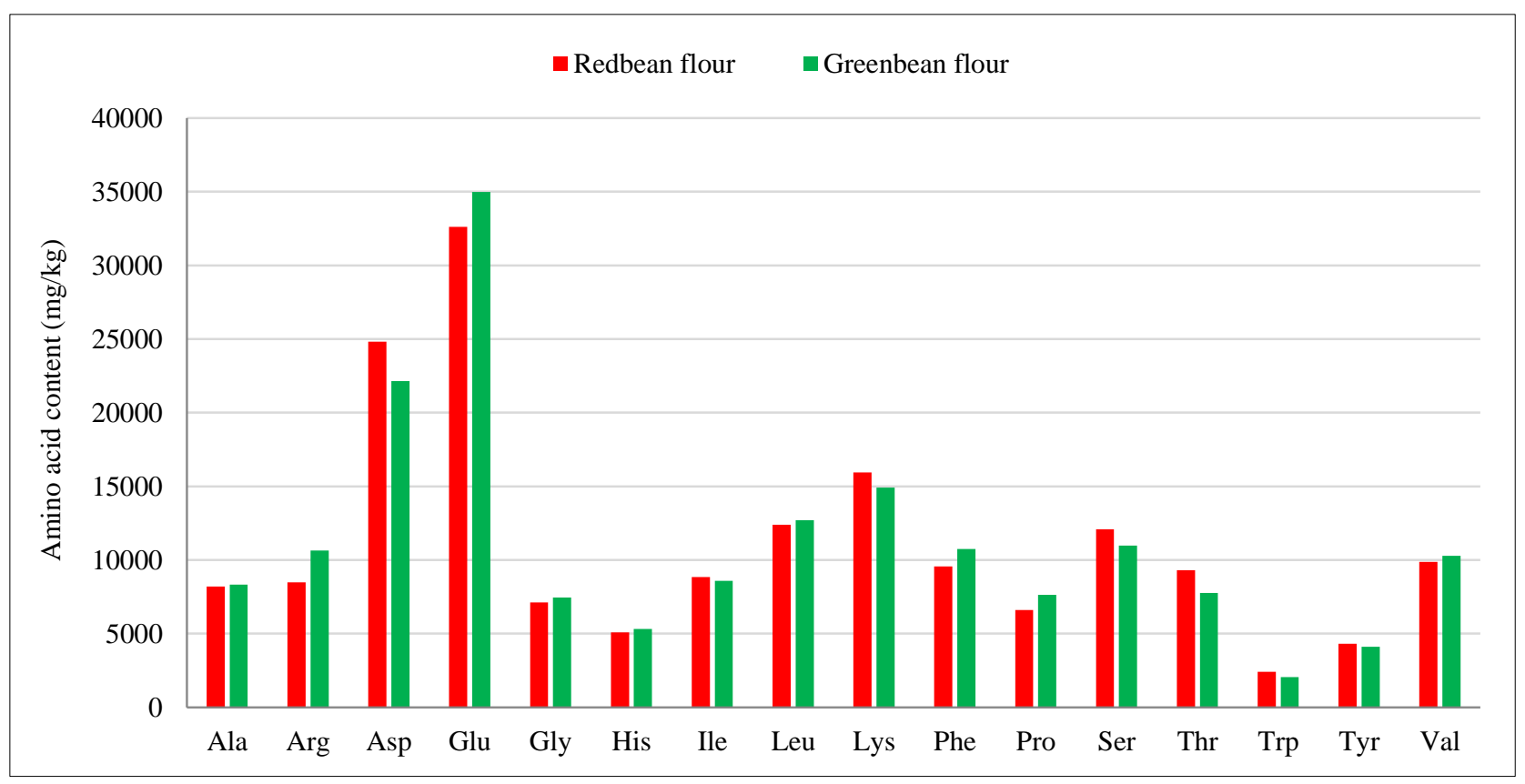

Figure 1. Amino acid analysis results $(\mathrm{mg} / \mathrm{kg})$ on red beans flour and green beans flour 
Glutamic acid has branched chains that are acidic and negatively charged. Glutamic acid has a very important role in food processing because it can cause delicious taste [19]. Glutamic acid in the body has several important functions, including as a neurotransmitter for brain development, a source of energy for the small intestine to absorb food juices, and as a biosynthetic ingredient in glutathione, alanine, aspartate, arginine and proline [21, 22].

The second highest amino acids in red bean flour and green beans are aspartic acid with a content of 24,808.14 $\mathrm{mg} / \mathrm{kg}$ and $22,154.11 \mathrm{mg} / \mathrm{kg}$, respectively. The human body naturally produces aspartic acid. In normal or healthy conditions, the need for aspartic acid is fulfilled by itself. Some of the benefits of aspartic acid include maintaining the body's metabolic system, increasing endurance by producing antibodies and immunoglobulins, producing energy as a source of energy for the body at the cellular level so that cell tissue activity works well, increasing brain concentration and memory, improving the transportation system minerals in the formation of DNA and RNA, and protect brain cells from ammonia toxins in the nervous system [3, 23].

Essential acids are amino acids needed for growth and excitement of body tissues [3]. In Figure 1, the largest essential amino acids found in red bean flour and green bean flour are the lysine amino acids of $15,929.89 \mathrm{mg} / \mathrm{kg}$ and $14,916.14 \mathrm{mg} / \mathrm{kg}$, respectively. Lysine amino acid is a type of amino acid with a chain of base branches and can be positively or negatively charged depending on the environment. Lysine is known as an amino acid which is needed as a building material for all proteins in the body. Lysine plays a major role in calcium absorption, and helps build muscle protein. Lysine is proven to help the human body absorb calcium, and plays an important role in the formation of collagen, a substance that is needed for bones and connective tissue such as skin, cartilage, and tendons [3,19].

The second largest essential amino acid in the raw material of red bean flour and green beans is leucine at $12,385.81 \mathrm{mg} / \mathrm{kg}$ and $12,694.86 \mathrm{mg} / \mathrm{kg}$, respectively. Leucine amino acids are considered as vital amino acids for protein synthesis and various metabolic functions. Leucine is an essential amino acid that helps in regulating blood sugar levels, promotes growth and recovery of muscle and bone tissue, as well as the production of growth hormones $[10,19]$.

Stunting children need essential amino acids such as lysine and leucine to support growth and body tissue during growth [2]. Thus red and green beans can be used as a source of protein, especially for stunting children, because it has the essential amino acids lysine and leucine that stunting children need to support growth and tissue.

\subsection{Identify the Isoelectric Point Of Red Bean and Green Bean Protein}

In this research, the isoelectric point identification of red bean and green bean protein has been carried out so that the deposition process occurs right at the isoelectric $\mathrm{pH}$. The process of identifying isoelectric points in this study cites the method used by Andoyo et al. (2015) in identifying isoelectric points on whey protein using a zetasizer. The isoelectric point was identified by conducting a zeta potential / electrophoretic mobility $\left(\mathrm{cm}^{2} / \mathrm{Vs}\right)$ test on samples that had been conditioned at various depositional pHs. The isoelectric point $(\mathrm{pI})$ is the $\mathrm{pH}$ at which the electrophoretic mobility $\left(\mathrm{cm}^{2} / \mathrm{Vs}\right)$ value is zero. In this study red bean and green bean samples were deposited at $\mathrm{pH} 3.00 ; 4.00$; and 5.00 .

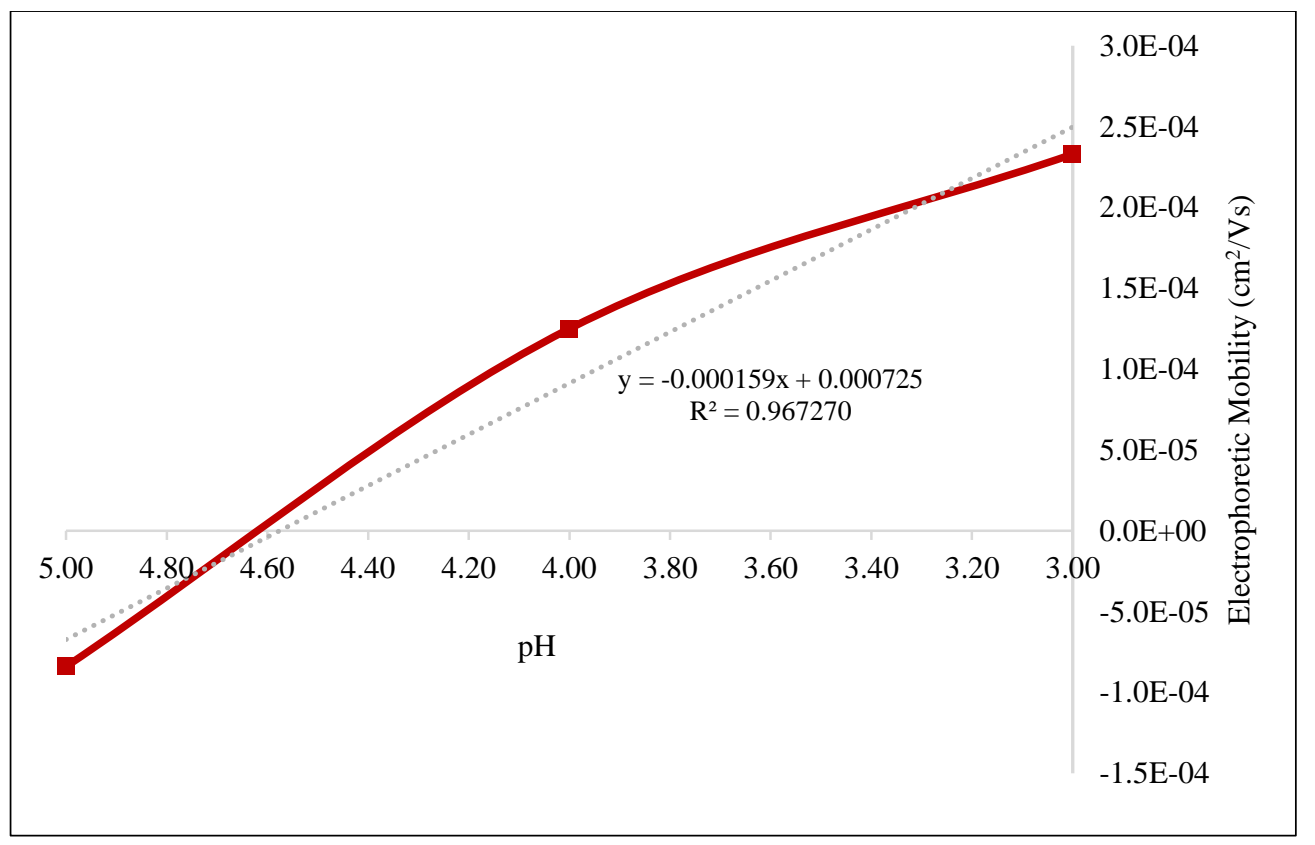

Figure 2. Graph of relationship between electrophoretic mobility value and $\mathrm{pH}$ of precipitation on red bean 


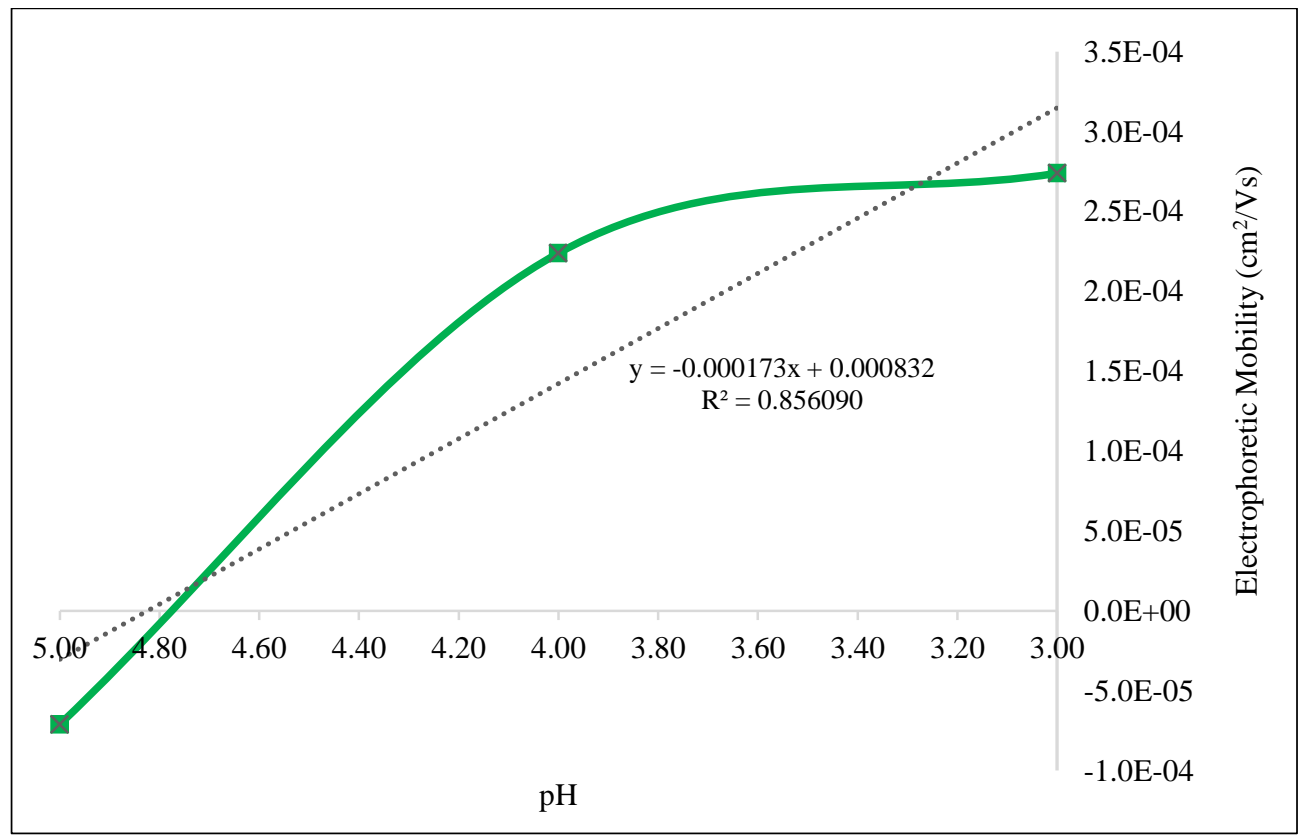

Figure 3. Graph of relationship between electrophoretic mobility value and $\mathrm{pH}$ of precipitation on green bean

\section{Calculation of Isoelectric pH (pI) of Red Bean Protein:}

Based on the zeta potential test results on red bean samples, electrophoretic mobility values were obtained at $\mathrm{pH}$ 3.00; $\mathrm{pH} 4.00$; and $\mathrm{pH} 5.00$, respectively are $0.000233 ; 0.000125$; and -0.000084 . The graph of the relationship between electrophoretic mobility and $\mathrm{pH}$ deposition of red bean protein can be seen in Figure 2.

Linear equation and $\mathrm{R}^{2}$ value can automatically be seen in the trendline menu in the graph, so that the following linear equation is obtained $\mathrm{y}=-0.000159 \mathrm{x}+0.000725$ with $\mathrm{R}^{2}=0.9672$. The value of $\mathrm{x}$ is $\mathrm{pH}$, while $\mathrm{y}$ is electrophoretic mobility. The isoelectric $\mathrm{pH}$ value is the $\mathrm{pH}$ value with electrophoretic mobility $\left(\mathrm{cm}^{2} / \mathrm{Vs}\right)$ equal to zero [15]. Then the result of the $\mathrm{x}$ value at $\mathrm{y}=0$ is the isoelectric $\mathrm{pH}$.

The isoelectric $\mathrm{pH}$ value of red bean protein is sought with the following calculation:

$$
\begin{aligned}
y & =-0.000159 x+0,000725 \rightarrow 0=-0.000159 x+0.000725 \rightarrow 0.000159 x=0,000725 \rightarrow \mathrm{x}=\frac{0.000725}{0.000159} \\
x & =4.5597 \approx 4.56
\end{aligned}
$$

The value of $\mathrm{x}$ at $\mathrm{y}=0$ is the value of $\mathrm{pI}$, then the red bean protein $\mathrm{pI}$ is 4.56 .

\section{Calculation of Isoelectric pH (pI) of Green Bean Protein:}

Whereas in the sample of green beans, electrophoretic mobility was obtained at a $\mathrm{pH}$ of 3.00; $\mathrm{pH} 4.00$; and $\mathrm{pH}$ 5.00 , respectively are $0.000274 ; 0.000224$; and -0.000071 . The graph of the relationship between electrophoretic mobility and $\mathrm{pH}$ deposition of red bean protein can be seen in Figure 3. Identification of the isoelectric point of green bean protein is identified in the same way with red bean protein. The resulting linear equation process is $y=-0.000173 \mathrm{x}$ +0.000832 with a value of $\mathrm{R}^{2}=0.8560$.The isoelectric $\mathrm{pH}$ value of green bean protein is sought with the following calculation:

$$
\begin{aligned}
& y=-0.000173 x+0.000832 \rightarrow 0=-0.000173 x+0.000832 \rightarrow 0.000173 x=0.000832 \rightarrow x=\frac{0.000832}{0.000173} \\
& x=4.8092 \approx 4.81
\end{aligned}
$$

The value of $\mathrm{x}$ at $\mathrm{y}=0$ is the value of $\mathrm{pI}$, so the green bean protein $\mathrm{pI}$ is 4.81 .

The isoelectric point of green bean protein is influenced by high aspartic and glutamic acid content [24]. This is consistent with the results of amino acid testing of red bean flour and green bean flour which contain glutamic acid and aspartic acid which is more dominant compared to other amino acids. Both of these amino acids have considerable anionic strength. This causes the $\mathrm{pH}$ conditions to be acidic enough to reduce the anionic strength so that the isoelectric point is reached. 

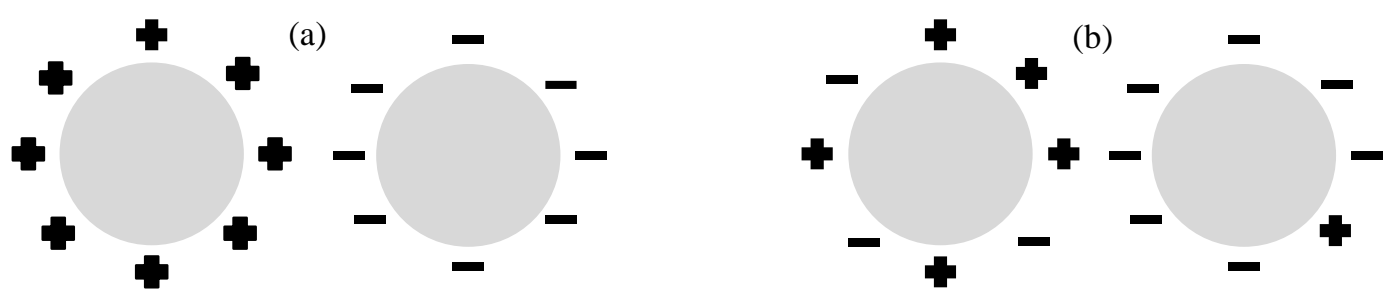

Figure 4. (a) Net Charge Condition / pI and (b) Not a Net Charge Condition

Protein molecules have amino groups (-NH2) and carboxylic groups (-COOH) at the ends of their chains [25]. This causes the protein to have a lot of charge (polyelectrolytes) and is amphoteric, which can react with acids and bases. In acidic or low $\mathrm{pH}$ solutions, the amino group in the protein will react with $\mathrm{H}+$ ions, so the protein is positively charged. Conversely, in alkaline or high $\mathrm{pH}$ solutions, the carboxylic group reacts with $\mathrm{OH}$ - ions, resulting in negatively charged proteins [26].

Protein molecules have several groups that contain unpaired $\mathrm{N}$ or $\mathrm{O}$ atoms. $\mathrm{N}$ atoms in the peptide chain are negatively charged so that they are able to attract $\mathrm{H}$ atoms from positively charged water. The attached water molecule can bind to other water molecules, because it has an $\mathrm{O}$ atom with unpaired electrons [25]. The isoelectric point is $\mathrm{pH}$ where the net charge / net charge condition is the sum of the positive charge residue (base) and the negative charge residue (acid) is neutral (Figure 4). At its isoelectric point, a protein shows electrostatic repulsion (repulsive force). Therefore protein will have the lowest solubility and will eventually settle easily.

\subsection{Isolation of Red Bean and Green Bean Protein}

The process of isolating red bean and green bean protein uses extraction and deposition methods at the isoelectric point. The weight of red bean flour used for the process of protein isolation is 40 grams. The process of protein isolation starts with mixing the ingredients with a ratio of red bean flour: distilled water is 1:10 (w/w). Then stir for 3 minutes. The same process is also carried out on raw materials for green bean flour.

The next process is checking the initial $\mathrm{pH}$. The average initial $\mathrm{pH}$ of red bean and green bean flour solutions was pH $6.47 \pm 0.23$ and $\mathrm{pH} 6.72 \pm 0.61$, respectively. The process of protein extraction must be carried out under alkaline conditions in order to extract a lot of protein, but alkaline conditions can also damage sulfur-containing amino acids such as tryptophan, threonine, lysine, and methionine [17]. Adjustment of the extraction $\mathrm{pH}$ is done by adding $0.5 \mathrm{~N}$ $\mathrm{NaOH}$ until the $\mathrm{pH}$ of the solution reaches the extraction $\mathrm{pH}(8.50-9.50)$. Then the solution is extracted at $30-50^{\circ} \mathrm{C}$ for 30-60 minutes.

The addition of distilled water as a solvent causes red bean flour and green bean flour to dissolve into distilled water by diffusion [27]. This results in less protein remaining in the residue. This interaction is based on the presence of the hydrophilic nature of the protein. The hydrophilic nature of proteins is caused by the presence of chains that have polar groups, such as carbonyl, hydroxyl, amino, carboxyl, and sulfhydryl, so that they can form hydrogen bonds with water [19].

Some amino acids have hydrophilic properties including arginine, asparagine, aspartic acid, cystine, glutamine, glutamic acid, glycine, histidine, lysine, serine, threonine, and tyrosine [3]. Based on research results, red bean flour and green bean flour are rich in glutamic acid, aspartic acid, lysine so it has the ability to absorb water. The number and types of different polar groups cause the ability of proteins to absorb water too.

The next process is centrifugation I. Red bean flour and green bean extraction solution is then carried out centrifugation process I at a speed of 4000 - $4500 \mathrm{rpm}$ for 15 minutes. The results of centrifugation I will separate the supernatant that contains dissolved protein and a large portion of carbohydrate residue [17]. The results showed that the residue still contained protein levels of $3.24 \pm 1.70 \%$ for red beans and $4.09 \pm 0.83 \%$ for green beans.

The supernatant which contains a portion of the protein is then precipitated at an isolate $\mathrm{pH}(\mathrm{pI})$ ie $\mathrm{pH} 4.56$ for red beans and $\mathrm{pH} 4.81$ for green beans. The $\mathrm{pH}$ adjustment is done by adding $2 \mathrm{~N} \mathrm{HCl}$ until the supernatant reaches isoelectric $\mathrm{pH}$. The deposition process was carried out at $30^{\circ} \mathrm{C}$ for 10 minutes. After that, the centrifugation II process at a speed of 4000 - $4500 \mathrm{rpm}$ for 15 minutes was carried out to obtain protein deposition.

The precipitate protein of red beans and green beans are then dried using freeze drying at a temperature of $-50^{\circ} \mathrm{C}$ for 24 hours. The choice of freeze drying method in the drying process aims to avoid protein from damage due to high temperatures $[9,18,28]$. Drying produces dry protein concentrate powder with a moisture content of $12.18 \pm 0.29 \%$ and $10.04 \pm 1.80 \%$, respectively. Based on the weight yield, red bean and green bean protein concentrate powder had a yield of $14.88 \%$ and $16.75 \%$, respectively.

Red bean and green bean protein concentrate powder had protein content of $79.22 \pm 0.06 \%$ and $80.69 \pm 0.06 \%$, respectively. Several other studies have also carried out isolation of green bean protein through protein extraction and 
precipitation methods resulting in $77.60 \%$ green bean protein sebanyak $77.60 \%$ [4], 77.32\% [18], and 77.57\% [27].

\section{Conclusion}

The results of this study indicate the protein content of the red bean and green bean protein concentrate is higher than the results of previous studies. However, further testing is needed regarding the optimum extraction conditions, and can be modified enzymatic hydrolysis to produce protein concentrates with high oligopeptide values. It is intended that the protein concentrate of green beans and red beans which are used as a source of protein in high-protein food formulations have good digestibility so that it can be a recommendation for children with stunting.

Red bean and green bean protein isolation techniques can be carried out through the extraction and precipitation process at isoelectric $\mathrm{pH}(\mathrm{pI})$, namely $\mathrm{pH} 4.56$ and $\mathrm{pH} 4.81$ respectively, and produce protein content.

\section{Acknowledgements}

The authors would like to thank the Ministry of Research, Technology and Higher Education, Universitas Padjadjaran.

\section{Declaration of Competing Interest}

The authors declare that they have no known competing financial interests or personal relationships that could have appeared to influence the work reported in this paper.

\section{Ethical Approval}

The conducted research is not related to either human or animal use.

\section{References}

[1] Yusuf, A.A., Komarulzaman, A., Alisjahbana, A.S., Anna, Z., Ghina, A.A., \& Megananda, A.S. (2018). Seri Menyongsong SDGs: Kesiapan Kabupaten/Kota di Provinsi Jawa Barat, Bandung: Unpad Press.

[2] Semba, R. D., Shardell, M., Sakr Ashour, F. A., Moaddel, R., Trehan, I., Maleta, K. M., ... Manary, M. J. (2016). Child Stunting is Associated with Low Circulating Essential Amino Acids. EBioMedicine, 6, $246-252$. doi:10.1016/j.ebiom.2016.02.030.

[3] Almatsier S., (2013) Prinsip Dasar Ilmu Gizi. Jakarta: PT. Gramedia Pustaka Utama, 2013.

[4] Wang, M., Jiang, L., Li, Y., Liu, Q., Wang, S., \& Sui, X. (2011). Optimization of Extraction Process of Protein Isolate from Mung Bean. Procedia Engineering, 15, 5250-5258. doi:10.1016/j.proeng.2011.08.973.

[5] Gunarti, D. R., Rahmi, H., \& Sadikin, M. (2013). Isolation and Purification of Thiamine Binding Protein from Mung Bean. HAYATI Journal of Biosciences, 20(1), 1-6. doi:10.4308/hjb.20.1.1.

[6] Yi-Shen, Z., Shuai, S., \& FitzGerald, R. (2018). Mung bean proteins and peptides: nutritional, functional and bioactive properties. Food \& Nutrition Research, 62(0). doi:10.29219/fnr.v62.1290.

[7] Kong, X., Li, X., Wang, H., Hua, Y., \& Huang, Y. (2008). Effect of lipoxygenase activity in defatted soybean flour on the gelling properties of soybean protein isolate. Food Chemistry, 106(3), 1093-1099. doi:10.1016/j.foodchem.2007.07.050.

[8] Dia, V. P., Wang, W., Oh, V. L., Lumen, B. O. d., \& de Mejia, E. G. (2009). Isolation, purification and characterisation of lunasin from defatted soybean flour and in vitro evaluation of its anti-inflammatory activity. Food Chemistry, 114(1), 108-115. doi:10.1016/j.foodchem.2008.09.023.

[9] Speroni, F., Milesi, V., \& Añón, M. C. (2010). Interactions between isoflavones and soybean proteins: Applications in soybeanprotein-isolate production. LWT - Food Science and Technology, 43(8), 1265-1270. doi:10.1016/j.lwt.2010.03.011.

[10] Thenawidjaja, M., Wangsa, T. I., \& Debbie, S. R. (2017). Protein Serial Biokimia Mudah dan Menggugah. Jakarta: Grasindo, 35.

[11] Andarwulan, N., (2019) "Plant-Based Protein as Functional Food Ingredients." in In Depth Seminar Internasional Foodreview Indonesia. Bogor, 14 Maret 2019.

[12] Helvich, K. (1990). Official methods of analysis (No. 630.24 A88 1990). Association of official analytical chemists (AOAC). Available online: https://law.resource.org/pub/us/cfr/ibr/002/aoac.methods.1.1990.pdf (accessed 26 March 2020 ).

[13] Association of official analytical chemists (AOAC), Tryptophan in Foods and Food and Feed Ingredient. Ion Exchange Chromatographic Method. AOAC International, 2005.

[14] Rohman, A., \& Gandjar, I. G. (2007). Metode Kromatografi Untuk Analisis Makanan. Yogyakarta: Pustaka Pelajar. 
[15] Andoyo, R., Guyomarc'h, F., Burel, A., \& Famelart, M.-H. (2015). Spatial arrangement of casein micelles and whey protein aggregate in acid gels: Insight on mechanisms. Food Hydrocolloids, 51, 118-128. doi:10.1016/j.foodhyd.2015.04.031.

[16] Lafarga, T., Álvarez, C., Bobo, G., \& Aguiló-Aguayo, I. (2018). Characterization of functional properties of proteins from Ganxet beans (Phaseolus vulgaris L. var. Ganxet) isolated using an ultrasound-assisted methodology. LWT, 98, $106-112$. doi:10.1016/j.lwt.2018.08.033.

[17] Kanetro, B. (2017). Teknologi Pengolahan dan Pangan Fungsional Kacang-Kacangan, Yogyakarta: Palantaxia.

[18] Du, M., Xie, J., Gong, B., Xu, X., Tang, W., Li, X., ... Xie, M. (2018). Extraction, physicochemical characteristics and functional properties of Mung bean protein. Food Hydrocolloids, 76, 131-140. doi:10.1016/j.foodhyd.2017.01.003.

[19] Winarno, F. G. (1991). Kimia Pangan Dan Gizi. PT Gramedia Pustaka Utama Press, Jakarta, Indonesia.

[20] Kusnandar, F., Andarwulan, N., \& Herawati, D. (2011). Analisis Pangan. Jakarta: Dian Rakyat.

[21] Agostoni, C., Carratù, B., Boniglia, C., Lammardo, A. M., Riva, E., \& Sanzini, E. (2000). Free Glutamine and Glutamic Acid Increase in Human Milk Through a Three-Month Lactation Period. Journal of Pediatric Gastroenterology and Nutrition, 31(5), 508-512. doi:10.1097/00005176-200011000-00011.

[22] Hertz, L., Dringen, R., Schousboe, A., \& Robinson, S. R. (1999). Astrocytes: glutamate producers for neurons. Journal of neuroscience research, 57(4), 417-428. doi: 10.1002/(sici)1097-4547(19990815)57:4<417::aid-jnr1>3.0.co;2-n.

[23] Music, Denis, Damian M. Holzapfel, Felix Kaiser, and Erik Wehr. "Aspartic Acid Adsorption on Thermoelectric Surfaces.” Applied Surface Science 496 (December 2019): 143716. doi:10.1016/j.apsusc.2019.143716.

[24] Akaerue, B. I., \& Onwuka, G. I. (2010). Evaluation of the Yeild, Protein Content and Functional Properties of Mungbean [Vigna radiata (L.) Wilczek] Protein Isolates as Affected by Processing. Pakistan Journal of Nutrition, 9(8), 728-735. doi:10.3923/pjn.2010.728.735.

[25] Hatti-Kaul, R., \& Mattiasson, B. (Eds.). (2003). Isolation and purification of proteins. CRC Press.

[26] Salgin, S., Salgin, U., \& Bahadir, S. (2012). Zeta potentials and isoelectric points of biomolecules: the effects of ion types and ionic strengths. Int. J. Electrochem. Sci, 7(12), 12404-12414.

[27] Mubarok, Z. R. (2019). Pengaruh Penambahan Asam Sitrat Pada Proses Perebusan Dan Perendaman Kedelai Untuk Mempercepat Proses Fermentasi Tempe. Jurnal Ilmiah Teknik Kimia, 3(1). doi:10.32493/jitk.v3i1.2596.

[28] Coscueta, E. R., Campos, D. A., Osório, H., Nerli, B. B., \& Pintado, M. (2019). Enzymatic soy protein hydrolysis: A tool for biofunctional food ingredient production. Food Chemistry: X, 1, 100006. doi:10.1016/j.fochx.2019.100006. 